\title{
ANALISIS GENDER TERHADAP KECEMASAN MATEMATIKA DAN SELF EFFICACY SISWA
}

\author{
Siti Imro'ah ${ }^{1}$, Widodo Winarso ${ }^{2}$, Edi Prio Baskoro ${ }^{3}$ \\ ${ }^{1}$ IAIN Syekh Nurjati Cirebon \\ sitiimroah210@gmail.com \\ ${ }^{2}$ IAIN Syekh Nurjati Cirebon \\ widodoiain@gmail.com \\ ${ }^{3}$ IAIN Syekh Nurjati Cirebon \\ edipriobaskoro@syekhnurjati.ac.id
}

\begin{abstract}
ABSTRAK
Siswa laki-laki maupun perempuan cenderung mengalami kecemasan ketika belajar matematika. Kecemasan matematika dapat diatasi oleh setiap siswa bergantung pada self-efficacy yang dimiliki siswa. Tingkat kecemasan matematika dan kemampuan self-efficacy diasumsikan memiliki kecenderungan yang berbeda jika dilihat dari perspektif gender. Sehingga penelitian ini bertujuan untuk menganalisis kecemasan matematika dan self-efficacy berdasarkan perbedaan jenis kelamin (gender). Metode yang digunakan dalam penelitian ini adalah metode kuantitatif dengan desain penelitian kausal komparatif. Populasi dalam penelitian ini adalah siswa SMP, dengan teknik Cluster Sampling diperoleh 38 siswa sebagai sampel penelitian. Instrumen yang digunakan adalah kuesioner. dengan teknik analisis data menggunakan independent sample t-test. Berdasarkan hasil penelitian, memiliki kecenderungan kecil pada cemasan matematika antara siswa laki-laki dan perempuan. dimana siswa perempuan lebih cemas jika dibandingkan dengan siswa laki-laki. Sedangkan pada self-efficacy siswa tidak ada perbedaan antara siswa laki-laki dan perempuan.
\end{abstract}

Kata Kunci: gender, kecemasan matematika, self-efficacy.

\begin{abstract}
Both male and female students tend to experience anxiety when learning mathematics. Mathematical anxiety can be overcome by each student depending on the student's self-efficacy. The level of mathematical anxiety and the ability of self-efficacy are assumed to have different tendencies when viewed from a gender perspective. So, this study aims to analyze mathematical anxiety and selfefficacy based on gender differences. The method used in this study is a quantitative method with comparative causal research design. The population in this study were students of Junior High School, with Cluster Sampling techniques obtained by 38 students as the research sample. The instrument used was a questionnaire. with data analysis techniques using independent sample t-test. Based on the results of the study, it has a small tendency towards mathematical anxiety between male and female students. where female students are more anxious when compared to male students. Whereas in student selfefficacy there is no difference between male and female students.
\end{abstract}

Keywords: gender, mathematical anxiety, self-efficacy 
Format Sitasi: Imro'ah, S., Winarso, W., \& Baskoro, E.P. (2018). Analisis Gender terhadap Kecemasaan Matematika dan Self Efficacy Siswa. KALAMATIKA Jurnal Pendidikan Matematika, 4(1), 23-36.

Penyerahan Naskah: 16 Agustus 2018 || Revisi: 12 April 2019 || Diterima: 12 April 2019

\section{PENDAHULUAN}

Sebagian besar bangsa di dunia sedang berproses dalam meningkatkan mutu pendidikan. hal tersebut diyakini bahwa kunci masa depan suatu bangsa ditentukan oleh keberadaan sistem pendidikan yang berkualitas. Sitem pendidikan berkualitas ditunjukkan dengan keberadaan sekolah-sekolah yang berkualitas pula (Welch, 2007).

Telah disadari atau tidak bahwa pendidikan dilakukan sepanjang zaman dan mempunyai peranan penting dalam kemajuan manusia. Adapun proses pendidikan tersebut dilakukan dengan cara belajar. Belajar juga merupakan proses perubahan prilaku seseorang dalam berbagai hasil dari pengalaman (Winarso, 2015).

Menurut hasil Third in International Mathematics Science and Study (TIMSS) 2011, peringkat anak-anak Indonesia bertengger di posisi 38 dari 42 negara untuk prestasi matematika, dan menduduki posisi 40 dari 42 negara untuk prestasi sains. Rata-rata skor prestasi matematika dan sains berturut-turut adalah 386 dan 406, masih berada signifikan di bawah skor rata-rata internasional (Fahmi, 2014). Indonesia perlu adanya upaya perbaikan dalam pembelajaran matematika sehingga prestasi belajar matematika di Indonesia dapat ditingkatkan. Berdasarkan survei tersebut memperlihatkan bahwa pendidikan matematika di Indonesia sangatlah rendah. Adapun salah satu faktor yang mempengaruhi dalam prestasi matematika siswa yaitu kecemasan.

Kecemasan yang dialami siswa pada mata pelajaran matematika biasanya disebut sebagai math anxiety/Kecemasan matematika (Perry, 2004). Kecemasan matematika tidak bisa dianggap remeh, karena ketidakmampuan siswa dalam beradaptasi menyebabkan siswa kesulitan terhadap matematika yang pada akhirnya menyebabkan hasil belajar dan prestasi siswa dalam matematika rendah (Winarso \& Supriady, 2016).

Menurut Tobias (1993), Kecemasan merupakan perasaan tidak tentram, khawatir, dan gelisah. Kecemasan merupakan gangguan psikologi yang bersifat wajar dan dapat timbul kapan dan dimanapun. Setiap orang pasti pernah mengalami kecemasan dengan tingkat yang berbedabeda. Rasa cemas dapat muncul dikarenakan terdapat suatu keadaan yang harus dihadapi atau 
diselesaikan. Freedman (2012), mengemukakan kecemasan matematika sebagai "an emotional reaction to mathematics based on past unpleasant experience which harms future learning". Sedangkan menurut Anita (2014), kecemasan adalah manifestasi dari berbagai proses emosi yang bercampur baur, yang terjadi ketika orang sedang mengalami tekanan perasaan (frustasi) dan pertentangan batin (konflik). Kecemasan merupakan gangguan dari dalam diri yang sudah menjadi bagian dari kehidupan manusia sehari-hari dan merupakan gejala yang normal. Setiap orang cenderung pernah merasakan kecemasan pada saat-saat tertentu, dan dengan tingkat yang berbeda-beda.

Conley dalam Fatma \& Ernawati (2012), berpendapat bahwa terdapat gejala umum dalam kecemasan dibagi menjadi dua terdiri dari; gejala somatic dan gejala psikologis. Gejala somatic dapat terlihat dari kondisi siswa ketika keringat berlebih, ketegangan pada otot skelet (sakit kepala, kontraksi pada bagian belakang leher atau dada, suara bergetar, dan nyeri punggung), sindrom hiperventilasi (sesak nafas, pusing, dan parestesi), gangguan fungsi gastrointestinal (tidak nafsu makan, mual, diare, dan konstipasi), iritabilitas kardiovaskuler (hipertensi). Sedangkan gejala psikologis, terdiri dari gangguan mood (sensitive, cepat marah, dan mudah sedih), kesulitan tidur (insomnia dan mimpi buruk), kelelahan dan mudah capek, kehilangan motivasi dan minat, perasaan-perasaan yang tidak nyata, sangat sensitif terhadap suara, berpikiran kosong (tidak mampu berkonsentrasi dan mudah lupa), kikuk, canggung, koordinasi buruk, tidak bias membuat keputusan, gelisah, resah, tidak bisa diam, kehilangan kepercayaan diri, kecenderungan untuk melakukan sesuatu secara berulang-ulang, keraguan dan ketakutan yang mengganggu, dan terus menerus memeriksa segala sesuatu yang telah dilakukan.

Menurut Nolen-Hoeksema, Stice, Wade \& Bohon (2007), bahwa terdapat empat tipe gejala kecemasan. Dimana keempat gejala kecemasan tersebut diantaranya a) Somatik, yaitu gejala kecemasan yang berhubungan dengan gerakan secara sadar, meliputi: Merinding, otot tegang, denyut jantung meningkat, bernafas tak teratur, menarik nafas, pupil melebar, asam lambung meningkat, air liur menurun dan lain sebagainya. b) Emosional, yaitu gejala kecemasan yang berhubungan dengan emosi, meliputi: Rasa takut, rasa diteror, gelisah, dan lekas marah. c) Kognitif, yaitu gejala kecemasan yang berhubungan dengan faktor kognitif, meliputi: Antisipasi dari bahaya, konsentrasi terganggu, rasa khawatir, suka termenung, kehilangan control, rasa takut mati, dan berpikir tidak realistik. d) Tingkah laku, meliputi: Melarikan diri, menghindari, dan lain sebagainya. 
Rasa cemas yang berlebihan terhadap matematika mempunyai dampak, baik itu dampak positif ataupun dampak negatif. Dampak positif terjadi apabila kecemasan itu muncul pada tingkat ringan sehingga dapat memberikan kekuatan untuk melakukan sesuatu untuk membantu individu membangun kepercayaan diri agar rasa cemas yang dirasakan dapat berkurang sedikit demi sedikit. Sedangkan dampak negatif terjadi apabila kecemasan muncul pada tingkat tinggi dan menimbulkan gejala fisik yang dapat berdampak terhadap hasil belajar siswa.

Kecemasan ketika mendapatkan pelajaran matematika itu bisa diatasi dengan berbagai cara. Salah satu cara untuk mengatasi rasa cemas ketika mendapatkan pelajaran matematika yaitu dengan meningkatkan efikasi diri pada siswa (Lee, 2009). Adapun, efikasi diri adalah keyakinan pada kemampuan diri sendiri dalam mengorganisir suatu tugas untuk mencapai hasil tertentu (Bandura, 1997). Efikasi diri akan berpengaruh pada prilaku seseorang, semakin tinggi efikasi diri seseorang, maka semakin besar kemungkinan hasil-hasil yang diharapkan akan dicapai. Seorang murid yang memiliki efikasi diri rendah, kemungkinan ia kurang memiliki usaha untuk belajar oleh sebab itu kurang percaya bahwa dengan belajar akan membantunya mampu mengerjakan soal-soal atau tugas-tugas yang harus diselesaikannya.

Efikasi diri dinilai sangat penting sebagai faktor internal yang mendorong siswa untuk berprestasi dan mempengaruhi pilihan siswa dalam aktivitas belajar, siswa dengan efikasi diri tinggi umumnya bersikap tekun dan tidak mudah menyerah ketika berhadapan dengan kegagalan ataupun kesulitan (Santrock, 2007). Efikasi diri ini merupakan kompetensi yang terkait pada aspek afektif. hal tersebutlah yang diharapkan dimiliki siswa setelah mempelajari matematika (Badriyah \& Winarso, 2018).

Terdapat beberapa hasil riset sebelumnya yang menunjukkan bahwa efikasi diri berdampak pada motivasi belajar peserta didik (Schunk, 1991; Pajares, 2003). Semakin tinggi efikasi diri, semakin besar motivasi belajar siswa. efikasi diri akan menentukan usaha dan ketekunan seseorang saat melakukan suatu tindakan dalam rangka mengejar tujuannya. Siswa yang memiliki keyakinan diri tinggi pada umumnya merasa diri kompeten sehingga mereka memiliki kemauan untuk terlibat dalam suatu kegiatan/tindakan.

Tak terlepas dari tujuan peningkatan pembelajaran matematika, ada beberapa faktor lain yang mempengaruhi efikasi diri salah satunya adalah jenis kelamin (O'brien, Martinez-Pons \& Kopala, 1999). Selain mempengaruhi efikasi diri, gender juga mempengaruhi hasil belajar siswa. Karena dalam proses belajar ada hal-hal yang menghambat dan menjadi faktor 
keberhasilan siswa dalam memperoleh hasil belajar yang baik. Faktor gender termasuk ke dalam potensi fisik dan psikis yang mempengaruhi hasil belajar siswa. Gender juga berpengaruh karena gender merupakan dimensi sosiokultural dan psikologis dari laki-laki dan perempuan (Santrock, 2007).

Berdasarkan hasil studi pendahuluan terhadap siswa SMP Negeri 1 Lemahabang ditemukan adanya kecemasan dan efikasi diri dalam pembelajaran matematika. Dari pernyataan beberapa guru matematika di SMP Negeri 1 Lemahabang, saat pembelajaran matematika berlangsung ada beberapa siswa yang merasa cemas dan ada beberapa siswa yang memiliki efikasi diri yang tinggi terhadap materi yang disampaikan guru matematika. Siswa yang cemas pada saat pembelajaran matematika disebabkan karena siswa cenderung malas belajar matematika sehingga pada saat pembelajaran matematika sering kali siswa merasa cemas, sedangkan siswa yang memiliki efikasi diri yang tinggi biasanya siswa tersebut rajin belajar.

Penelitian ini tentang analisis gender terhadap kecemasan matematika dan efikasi diri siswa. Berdasarkan uraian pendahuluan di atas, maka dapat dirumuskan masalah penelitian ini adalah apakah terdapat perbedaan kecemasan matematika dan efikasi diri antara siswa laki-laki dan perempuan.

\section{METODE PENELITIAN}

Penelitian ini dilaksanakan di SMP Negeri 1 Lemahabang kabupaten Cirebon. Metode penelitian yang digunakan yaitu Kausal Komparatif (Ragin, 2014). Populasi penelitian adalah siswa kelas VII SMP Negeri 1 Lemahabang yang berjumlah 334 siswa yang terbagi dalam 9 kelas. Adapun dalam penelitian ini untuk menentukan sampelnya peneliti menggunakan cara Random Sampling (Allen, et.al, 2002). Dari jumlah 334 siswa yang terdiri dari 9 kelas, secara acak terpilih kelas VII-I sebagai kelas yang dijadikan sampel dalam penelitian ini dengan jumlah siswa 38 orang.

Alat pengumpulan data yang digunakan adalah survey berupa Intrumen angket atau kuesioner. Menurut Riduwan (2010) angket adalah daftar pernyataan yang diberikan kepada siswa sebagai subjek penelitian untuk memberikan respon berdasarkan permintaan peneliti.

Adapun Instrumen penelitian (angket) yang digunakan telah melalui proses uji coba instrumen dengan berbagai jenis perhitungan data uji coba instrumen sehingga valid dan dapat mengukur variabel penelitian. Selanjutnya data hasil penelitian dihitung kenormalitasan dan kehomogenan suatu data sebelum dilakukan uji statistik lanjut. Adapun uji hipotesis penelitian 
ini menggunakan independent sample t-test. Independent sample t-test sering digunakan guna menguji perbedaan antara dua kelompok sampel yang bebas (Priyatno, 2011). Independent sample t-test merupakan teknik statistik inferensial yang memiliki tujuan untuk uji komparatif atau uji beda untuk mengetahui adakah perbedaan mean atau rerata yang bermakna antara 2 kelompok bebas yang berskala data interval/rasio. Dua kelompok bebas yang dimaksud di sini adalah dua kelompok yang tidak berpasangan, artinya sumber data berasal dari subjek yang berbeda (Subana, 2000).

\section{HASIL DAN PEMBAHASAN}

Menurut Ashcraft (2002), kecemasan matematika (mathmatics anxiety) yaitu sebuah perasaan tegang, cemas atau ketakutan yang mengganggu kinerja matematika. Siswa yang mengalami kecemasan matematika cenderung menghindari situasi dimana mereka harus mempelajari dan mengerjakan matematika. Kecemasan matematika dapat diukur mengunakan angket kecemasan matematika disebarkan kepada siswa kelas VII-I. Dengan proporsi sebanyak 14 siswa laki-laki dan 24 siswa perempuan. Berdasarkan penyebaran skor angket kecemasan matematika diperoleh perhitungan statistik deskriptif sebagai berikut.

Tabel 1. Deskripsi Skor Hasil Angket Kecemasan Matematika

\begin{tabular}{lcc}
\hline & Laki-laki & Perempuan \\
\hline Mean & 77,09 & 80,09 \\
Median & 78 & 82 \\
Variance & 73,09 & 128,29 \\
Std. Deviation & 8,55 & 11,32 \\
Minimum & 60 & 58 \\
Maximum & 91 & 105 \\
Range & 31 & 45 \\
\hline
\end{tabular}

Berdasarkan Tabel 1, hasil perhitungan deskriptif statistik angket kecemasan matematika siswa berdasarkan jenis kelamin, diperoleh bahwa siswa perempuan cenderung memiliki kecemasan matematika lebih tinggi, jika dibandingkan dengan siswa laki-laki.

Menurut Harry (dalam Nolen-Hoeksema, Stice, Wade \& Bohon, 2007) berpendapat bahwa terdapat empat gejala kecemasan, yaitu somatik, emosional, kognitif, dan tingkah laku. Adapun rekapitulasi dari masing-masing persentase aspek dapat dilihat pada grafik berikut. 


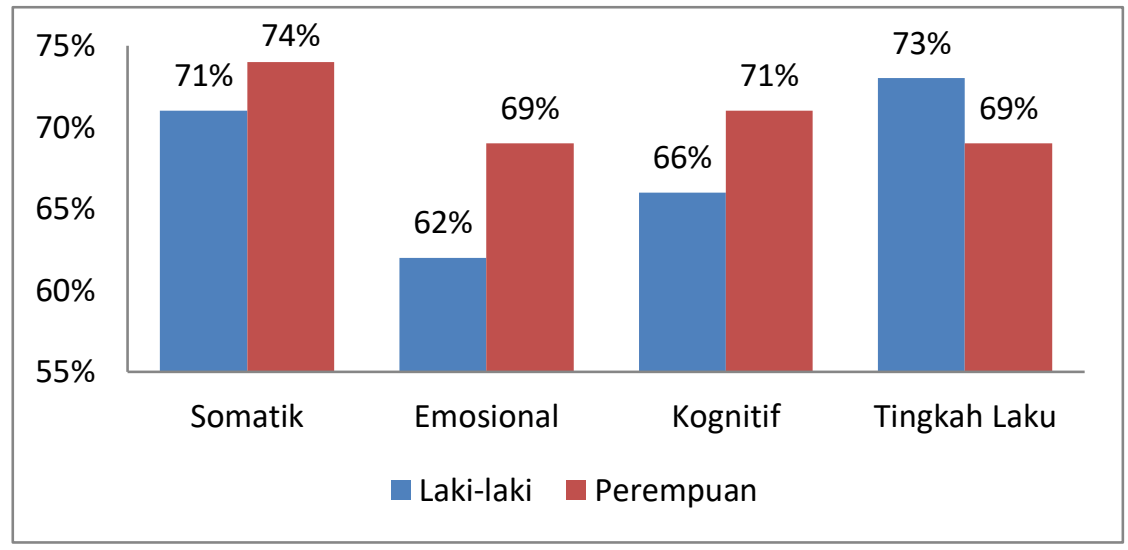

Gambar 1. Proporsi Aspek Kecemasan Matematika Siswa

Berdasarkan Gambar 1. presentase perempuan lebih cemas dibandingkan laki-laki, dapat diketahui pada aspek somatik perempuan lebih tinggi daripada laki-laki, aspek emosional perempuan lebih tinggi daripada laki-laki, aspek kognitif perempuan lebih tinggi daripada lakilaki, aspek tingkah laku laki-laki lebih tinggi daripada perempuan. Sehingga dapat dirataratakan bahwa kecemasan matematika siswa perempuan lebih tinggi dari kecemasan matematika siswa laki-laki.

\section{Deskripsi Efikasi Diri Siswa Berdasarkan Gender}

Menurut Bandura (1997) efikasi diri atau self-efficacy merupakan bagai keyakinan siswa dalam kemampuan untuk melakukan sesuatu dalam bentuk kontrol terhadap fungsi siswa yang lain dan kejadian dalam lingkungan belajar. Adapun untuk mengukur efikasi diri, menggunakan angket efikasi diri yang disebarkan pada siswa kelas VII-I. Berdasarkan penyebaran skor angket efikasi diri siswa diperoleh perhitungan statistik deskriptif seperti Tabel 2.

Tabel 2. Deskripsi Skor Hasil Angket Efikasi Diri Siswa

\begin{tabular}{lcc}
\hline & Laki-laki & Perempuan \\
\hline Mean & 81,55 & 84 \\
Median & 81 & 83 \\
Variance & 63,07 & 135,70 \\
Std. Deviation & 7,94 & 11,64 \\
Minimum & 68 & 67 \\
Maximum & 98 & 113 \\
Range & 30 & 46 \\
\hline
\end{tabular}

Berdasarkan Tabel 2, hasil perhitungan deskriptif statistik angket efikasi diri siswa berdasarkan jenis kelamin, diperoleh bahwa untuk siswa perempuan lebih dapat membangun kemampuan efikasi dirinya jika dibandingkan dengan siswa laki-laki. 
Bandura (1997), menyatakan bahwa efikasi diri tiap individu akan berbeda antara satu individu dengan yang lainnya berdasarkan tiga aspek, yaitu tingkat (level), kekuatan (strength), dan generalisasi (generality). Hasil penyebaran angket efikasi diri dari masing-masing aspek dapat dilihat pada Gambar 2.

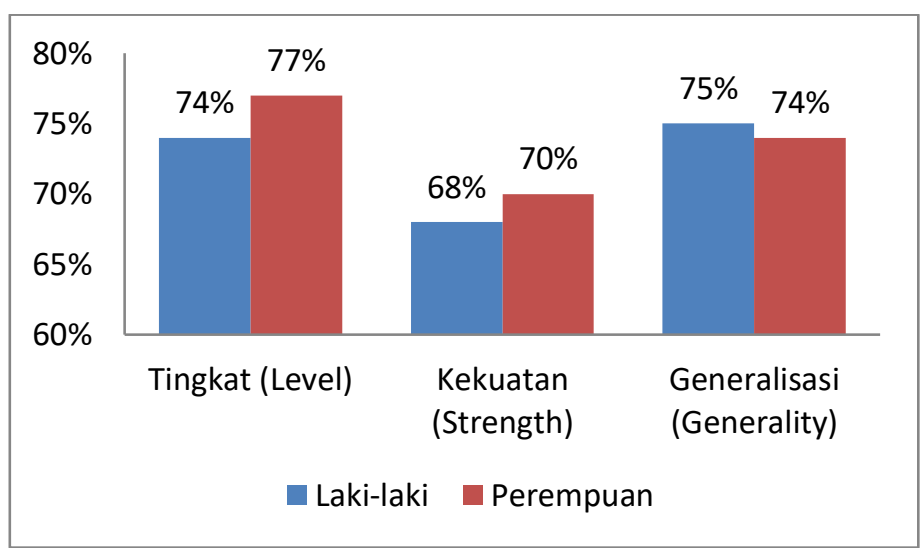

Gambar 2. Proporsi aspek efikasi diri

Berdasarkan aspek-aspek efikasi diri, terlihat pada Gambar 2 bahwa pada aspek tingkat (level) dan aspek kekuatan, siswa perempuan memiliki persentase skor yang lebih tinggi dibandingkan siswa laki-laki, tetapi untuk aspek generalisasi tidak memiliki perbedaan yang begitu jauh.

Berdasarkan perolehan data penelitian yaitu data kecemasan belajar dan efikasi diri. Selanjutnya analisis data dilakukan pengujian hipotesis penelitian. Perhitungan uji hipotesis menggunakan uji Independent samples t-test dengan berbantuan software SPSS. Adapun hasil perhitungan uji hipotesis penelitian dapat dilihat melalui Tabel 3.

Tabel 3. Uji Independent Sampel t-test

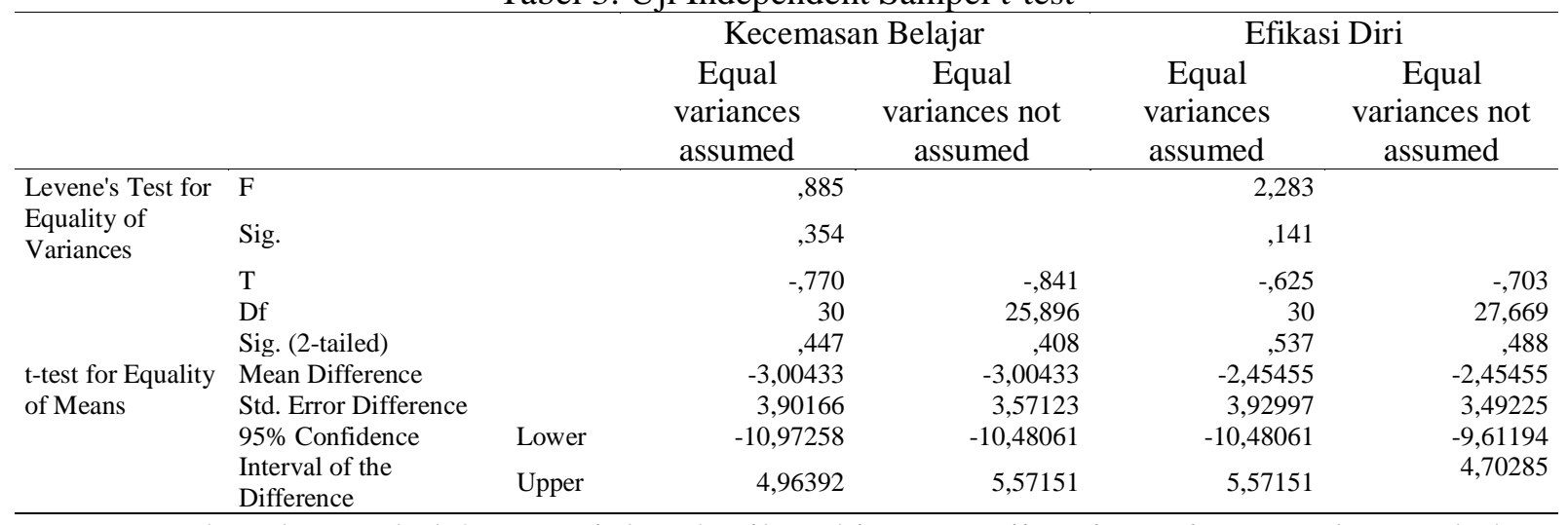

Berdasarkan Tabel 3. Menujukan hasil perhitungan uji independen sample t-tes bahwa

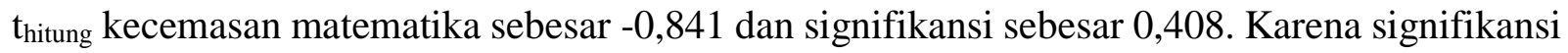
lebih dari 0,05 maka Ho diterima yang artinya tidak ada perbedaan gender terhadap kecemasan 
belajar matematika siswa pada sampel penelitian. Sedangkan untuk efikasi diri diketahui bahwa $t_{\text {hitung }}$ efikasi diri siswa sebesar -0,703 dan signifikansi sebesar 0,488. Karena signifikansi lebih dari 0,05 maka Ho diterima yang artinya tidak ada perbedaan kecemasan matematika berdasarkan perbedaan gender siswa.

\section{PEMBAHASAN}

Berdasarkan pemaparan tiap aspek kecemasan belajar matematika siswa, rata-rata persentase kecemasan belajar matematika siswa laki-laki sebesar $68 \%$ dan siswa perempuan sebesar 70,75\%. Siswa perempuan memiliki kecemasan matematika lebih tinggi daripada siswa laki-laki namun tidak memiliki makna perbedaan secara signifikan. Begitu juga dengan pemaparan tiap aspek dari variabel efikasi diri siswa, maka dapat dimaknai bahwa rata-rata persentase efikasi diri siswa laki-laki sebesar 72,3\% dan siswa perempuan sebesar 73,7\%. Sehingga dapat maknai bahwa siswa perempuan memiliki efikasi diri lebih tinggi dari pada siswa laki-laki namun perbedaan tersebut juga tidak memiliki makna perbedaan secara signifikan.

Peran gender yang menetapkan matematika lebih domain siswa laki-laki dibandingkan siswa perempuan, siswa perempuan yang mungkin lebih mau mengakui perasaan cemas atau lebih kritis terhadap diri sendiri daripada siswa laki-laki, serta siswa perempuan lebih memiliki kepercayan diri lebih tinggi dibandingkan siswa laki-laki.

Menurut Kruteski (Nafi'an, 2011) perbedaan antara siswa laki-laki dan perempuan dalam belajar matematika sebagai berikut: 1) Laki-laki lebih unggul dalam penalaran, perempuan lebih unggul dalam ketepatan, ketelitian kecermatan, dan keseksamaan berpikir. 2) Laki-laki memiliki kemampuan matematika dan mekanika yang lebih dari perempuan, perbedaan ini tidak terlihat jelas pada tingkat dasar akan tetapi menjadi tampak lebih jelas pada tingkat yang lebih tinggi.

Uji prasyarat hipotesis seperti uji normalitas dan homogenitas data keduanya memiliki ciri signifikansi lebih dari 0,05. Sehingga disimpulkan bahwa data penelitian berdistribusi normal dan homogen. Berdasarkan hasil uji hipotesis penelitian menggunakan uji independent sample t-test diketahui bahwa signifikansi kecemasan belajar matematika dan efikasi diri siswa adalah 0,408 dan 0,488. Karena kedua signifikansi lebih dari 0,05 sehingga dapat disimpulkan tidak ada perbedaan gender terhadap kecemasan belajar matematika dan efikasi diri siswa walaupun hasil hasil analisis deskriptif dinyatakan berbeda. 
Sampel penelitian yang digunakan memiliki karakteristik bahwa perbedaan jenis kelamin tidak memberikan perbedaan kecemasan belajar matematika maupun efikasi diri siswa. Sehingga perbedaan biologis tidak menimbulkan perbedaan untuk kecemasan belajar dan efikasi diri. Hal ini dapat ditinjau dari hasil perhitungan analisis respon angket penelitian kecemasan belajar matematika dan efikasi diri siswa yang telah isi oleh masing-masing siswa. Untuk lebih jelasnya dari hasil persentase angket kecemasan belajar diketahui bahwa rata-rata persentase laki-laki sebesar $68 \%$ dan perempuan sebesar $70,75 \%$ sehingga jika diperhatikan tidak ada perbedaan rata-rata yang signifikan. Hasil persentase angket efikasi diri siswa diketahui bahwa rata-rata persentase laki-laki sebesar $72,3 \%$ dan perempuan sebesar $73,7 \%$ sehingga jika diperhatikan tidak ada perbedaan rata-rata yang signifikan.

\section{KESIMPULAN}

Berdasarkan hasil analisis dan pengujian statistik, penelitian ini menghasilkan kesimpulan bahwa kecemasan perempuan lebih tinggi dibandingkan kecemasan laki-laki. Dengan rata-rata presentase pada siswa perempuan 70,75\% sedangkan laki-laki sebesar $68 \%$ artinya terdapat selisih 2,75\%. Hal ini dapat dilihat dari setiap aspek, dimana aspek somatik somatik siswa laki-laki $71 \%$ dan perempuan 74\%, aspek emosional siswa laki-laki $62 \%$ dan perempuan 69\%, aspek kognitif siswa laki-laki 66\% dan perempuan 71\%, dan aspek tingkah laku siswa laki-laki 73\% dan perempuan 69\%. Selain itu, efikasi diri perempuan lebih tinggi dibandingkan efikasi diri laki-laki. Dengan rata-rata presentase pada siswa perempuan 73,7\% sedangkan laki-laki sebesar 72,3\% artinya terdapat selisih 1,4\%. Hal ini dapat dilihat dari setiap aspek, dimana aspek tingkat (level) siswa laki-laki 74\% dan perempuan 77\%, aspek kekuatan (strength) siswa laki-laki 68\% dan perempuan 70\%, dan aspek generalisasi ( generality) siswa laki-laki $75 \%$ dan perempuan $74 \%$.

Kesimpulan lain yang diperoleh adalah tidak terdapat perbedaan gender dalam kecemasan matematika siswa. Hal ini dapat dilihat dari hasil perhitungan angket bahwa signifikansi kecemasan matematika sebesar 0,408 sehingga jika diperhatikan tidak ada perbedaan kecemasan yang signifikan. Selain itu, tidak ada perbedaan gender atau jenis kelamin terhadap efikasi diri siswa. Hal ini dapat dilihat dari hasil perhitungan angket bahwa signifikansi efikasi diri sebesar 0,488 sehingga jika diperhatikan tidak ada perbedaan efikasi diri yang signifikan. 


\section{REKOMENDASI}

Guru mengupayakan menggunakan metode mengajar yang lebih variatif dan humanis, seperti menciptakan suasana belajar yang menyenangkan, tidak tegang, serta guru juga harus lebih humoris dan tidak terlalu keras dalam mengajar matematika. Sehingga melalui setting belajar semacam itu dapat menciptakan pemebalajaran yang lebih kondusif. Peserta didik juga harus bisa meminimalisir rasa cemas terhadap pelajaran matematika ataupun pelajaran yang lain, agar materi pembelajaran dapat diserap dengan baik oleh siswa.

\section{REFERENSI}

Allen, M., Kilpatrick, D., Armstrong, M., Briggs, R., Course, G., \& Pérez, N. (2002). Multistage cluster sampling design and optimal sample sizes for estimation of fish discards from commercial trawlers. Fisheries Research, 55(3), 11-24.

Anita, I. W. (2014). Pengaruh kecemasan matematika (mathematics anxiety) terhadap kemampuan koneksi matematis siswa SMP. Infinity Journal, 3(1), 125-132.

Ashcraft, M. H. (2002). Math anxiety: Personal, educational, and cognitive consequences. Current directions in psychological science, 11(5), 181-185.

Badriyah, U., \& Winarso, W. (2018). Korelasi Tingkat Kepercayaan Diri Terhadap Prestasi Belajar Mahasiswa di IAIN Syekh Nurjati Cirebon (Studi Pada Calon Pendidik Matematika). Jurnal Pendidikan Matematika, 5(2), 15-29.

Bandura, A. (1997). Self-efficacy: The exercise of control (pp. 3-604). New York: WH Freeman.

Fahmi, S. (2014). Pengembangan multimedia macromedia flash dengan pendekatan kontekstual dan keefektifannya terhadap sikap siswa pada matematika. Jurnal AgriSains, 5(2). 166191

Fatma, A., \& Ernawati, S. (2012). Pendekatan Perilaku Kognitif dalam PelatihanKeterampilan Mengelola Kecemasan Berbicara di Depan Umum. Talenta Psikologi, 1(1), 39-65.

Freedman, E. (2013). Do you have math anxiety? A self test. Retrieved August, 10, 2004. www. mathpower. com/anxtest. htm. 
Lee, J. (2009). Universals and specifics of math self-concept, math self-efficacy, and math anxiety across 41 PISA 2003 participating countries. Learning and individual differences, 19(3), 355-365.

Nafi'an, M. I. (2011, December). Kemampuan siswa dalam menyelesaikan soal cerita ditinjau dari gender di sekolah dasar. In Seminar Nasional Matematika dan Pendidikan Matematika (pp. 571-577).

Nolen-Hoeksema, S., Stice, E., Wade, E., \& Bohon, C. (2007). Reciprocal relations between rumination and bulimic, substance abuse, and depressive symptoms in female adolescents. Journal of abnormal psychology, 116(1), 198-207.

O'brien, V., Martinez-Pons, M., \& Kopala, M. (1999). Mathematics self-efficacy, ethnic identity, gender, and career interests related to mathematics and science. The Journal of Educational Research, 92(4), 231-235.

Pajares, F. (2003). Self-efficacy beliefs, motivation, and achievement in writing: A review of the literature. Reading \&Writing Quarterly, 19(2), 139-158.

Perry, A. B. (2004). Decreasing math anxiety in college students. College student journal, 38(2), 321-325.

Priyatno, D. (2011). Buku Saku SPSS Analisis Statistik Data Lebih Cepat, Efisien, dan Akurat. Yogyakarta: MediaKom.

Ragin, C. C. (2014). The comparative method: Moving beyond qualitative and quantitative strategies. Univ of California Press.

Riduwan. (2010). Belajar Mudah Penelitian Untuk Guru: Karyawan dan Peneliti Pemula. Bandung: Alfabeta

Santrock, J. W. (2007). Psikologi Pendidikan edisi kedua. Jakarta: Kencana Pranada Media Grup 
Schunk, D. H. (1991). Self-efficacy and academic motivation. Educational psychologist, 26(34), 207-231.

Subana, M. (2000). Statistik Pendidikan. Bandung: CV Pustaka Setia.

Tobias, S. (1993). Overcoming math anxiety. New York : WW Norton \& Company.

Welch, A. R. (2007). Blurred vision: Public and private higher education in Indonesia. Higher Education, 54(5), 665-687.

Winarso, W. (2015). Dasar Pengembangan Kurikulum Sekolah. Cirebon: CV. Confident

Winarso, W., \& Supriady, D. (2016). Menilai Prestasi Belajar melalui Penguatan Self Regulated Learning dan Kecerdasan Emosional Siswa pada Pembelajaran Matematika. Jurnal Didaktik Matematika, 3(2). 54-66. 
